\title{
Addressing Cultural And Religious Intolerance For Effective Teaching, Learning And Peace Of The Primary School Children In Zimbabwe: A Case Study Of Shurugwi District Schools.
}

\author{
Thondhlana Saiden \\ Lecturer Department of Educational Studies \\ Zimbabwe Open University \\ Makawa James. D. (PhD) \\ Higher Degrees Supervisor \\ Zimbabwe Open University
}

\begin{abstract}
The study was aimed at establishing the effect of religion and culture on effective teaching, learning and peace. It was a follow up study of a similar study undertaken in Gweru District primary schools. The study was qualitative and used a case study design. The study was informed by ethnography. The sample for the study consisted of 93 teachers, 60 primary school children, 1 District schools' inspector and 2 conflict resolution experts. The respondents were conveniently chosen in the mean while conflict resolution experts were chosen by snow-balling. The findings were that ethnocentrism and xenocentrism was rampant, negatively affecting effective teaching, learning and peace in the primary schools. It was also found out there was no religious and cultural appreciation impacting negatively on teaching, learning and peace. Fundamentalism also exists. It was recommended inter-alia that multicultural education and inter-faithism be introduced in the primary school system.
\end{abstract}

Key Terms: Ethnocentrism, xenocentrism, teaching, learning, peace, multiculturalism, interfaithism

\section{INTRODUCTION}

Conflict in any organisation is inevitable (Sellman, 2003; Kreitner and Kinicki, 1997; Jandt, 1985; Deutsch, 1993). Ferguson (1977) points out that multiple ideas and beliefs result in conflict because of the production of opposing actions and vehicles. Conflict among primary school children (and even among teachers) usually arises due to their different cultural and religious backgrounds (Moix, 2006). When conflict is resolved well, research has shown this leads to effective teaching, learning and peace in the primary schools (Sellman, 2003). Culture and religion play a positive role if multiculturalism and inter-faithism are instituted in the school system (McGettrick, 2005; Mason, 2015; Ngara and Chang, 1985). Culture and Religion play a negative role when opposing aspects of these are upheld.

The Constitution of Zimbabwe stipulates that children have their rights and they should not be discriminated against due to their gender, language, culture, religion, class, tribe, or social status (Zimbabwe Constitution, 2013). The Constitution calls for multiculturalism and interfaithism in Zimbabwe primary schools. These two aspects seem to be lacking in the Zimbabwe school system for there have been calls to Africanise the school curriculum (Mavhunga, 2006), to introduce the teaching and learning of African Traditional medicine and culture in the school curriculum (Kazembe, 2010), incorporation of both African Culture and Western culture in the 
curriculum (Ngara and Chung, 1985) and incorporation of the indigenous knowledge system in the school curriculum (Matsika, 2012). Further, to multiculturalism and inter-faithism Manson (2005) advocates for a rights-based approach to diversity in schools to maintain unity.

A study of the primary school Religious and moral education (RME) curriculum undertaken in Masvingo Province in Zimbabwe by Marashe, Ndamba and Chireshe (2009) revealed that the RME curriculum was predominantly Christianity. Xenocentrism and ethnocentrism is present in the Zimbabwe primary schools as reported in the Sunday News, July 15 (2014); Standard, June 29 (2014) and Nehanda Radio, July 22 (2014).

Finally the researcher's experience as a teacher and a head of primary schools in Shurugwi and Mberengwa Districts for twenty-two years made him aware of the existence of xenocentrism and ethnocentrism in schools in the districts. This study was a follow up of a similar study undertaken in Gweru District primary schools.

\section{STATEMENT OF THE PROBLEM}

Ethnocentrism and xenocentrism are rampant in Zimbabwean primary schools. Christianity and the dominant culture in communities are dominating the Religious and Moral Education curriculum at primary school level and relationships in the communities compromising effective learning, teaching and peace in the schools. The main research question is "How are religion and cultutre influencing conflict resolution in the Primary schools in Gweru District in the Midlands Province of Zimbabwe and how can these be rectified?

\section{Research Sub-Problems}

The research sub-problems that led to the answering of the main research question were:

1. To what extent does xenocentrism affect conflict resolution in Gweru District primary schools?

2. To what extent does ethnocentrism affect conflict resolution in Gweru District primary schools?

3. How can conflict resolution be influenced positively through culture and religion in Gweru District primary schools?

\section{PURPOSE OF THE STUDY}

The study aimed at establishing how religion and culture influenced conflict resolution in the primary schools in Zimbabwe. It also aimed at the establishment of how religion and culture could be addressed so that there could be effective learning, teaching and peace in the primary schools.

\section{SIGNIFICANCE OF THE STUDY}

The study was significant to the Ministry of Primary and Secondary Education policy makers and Curriculum designers in that they would discover how religion and culture affected effective teaching, learning and peace therefore, take corrective action. The study was also significant to Heads of schools and teachers in the primary schools in that they would be made aware of religion and culture and how they affect conflict resolution and how these could be eradicated to facilitate effective learning, teaching and peace.

The study was significant as well to the pupils in that their learning, teaching and peace would be facilitated because of the existence of a peaceable atmosphere. The parents were also to benefit in that they would learn ways of addressing xenocentrism and ethnocentrism that causes divisions in their communities and hence affect the unity of community members. 


\section{LIMITATIONS OF THE STUDY}

The study had some limitations. The first limitation was that the study was a case study so the data collected could not be generalised for the whole country because the study was confined to one district. Thus the strategies could not be applied to all districts in the country.

This limitation was circumvented by triangulation of sources of information and data gathering techniques.

Other limitations were the use of paper questionnaires, research assistants and the distance from Gweru of some schools in the sample which made the exercise to be expensive. The researcher made use of opportunities that arose from visits to student teachers posted in the district under study.

Another limitation was that one of the languages spoken in the district namely Ndebele made it difficult for the researcher to communicate directly with participants. The use of research assistants minimised the challenge.

\section{DELIMITATIONS OF THE STUDY}

The study was delimited to primary schools in the Gweru District of the Midlands Province of Zimbabwe. Only participants from schools that could be accessed were invited to participate. The study focused on the effects of religion and culture on conflict resolution in the primary schools and ways of eradicating them.

\section{ETHICAL AND LEGAL CONSIDERATIONS}

The researcher took into consideration ethical and legal considerations of protection of subjects from harm, the right to privacy, the issue of informed consent, the issue of avoiding deception and the right of participants to participate freely. The above issues were pointed out by Merriam (2009) as important issues to be taken care of in every study.

\section{REVIEW OF RELATED LITERATURE}

In reviewing related literature the following reviews are made; conceptual framework, theoretical framework and reviews of empirical literature.

\section{Conceptual framework}

Quite a number of concepts have to be clarified so that the study results are understood. The terms that require clarification are; conflict; conflict resolution; teaching, learning, peace, ethnocentrism, xenocetrism, culture, religion, multiculturalism and inter-faithism.

\section{Conflict}

Rue and Byars (2003, p.285) view conflict as "an overt behaviour that results when an individual or group of individuals think a perceived need of the individual or group has been blocked or is about to be blocked". This definition stresses the importance of basic needs like physiological needs, security needs, social needs, self-esteem and self-actualisation (Maslow, 1991). Stoner, Freeman and Gilbert (1995, p.539) are of the view that conflict involves "a disagreement about allocation of scarce resources or a clash of goals, status, values, perceptions or personalities. In the same vein Ministry of Primary and Secondary Education (2010) views conflict as happening when there is a disagreement about issues. Tumbo and Moyo (2013) define conflict as an absence of peace which involves fighting among people or groups and some misunderstandings among people or parties. 


\section{Conflict Resolution}

Lam, (1988) contend that conflict resolution aims to end conflict before it starts to lead to physical fighting. Bamboo, Web Dictionary (2006) contend that conflict resolution is the process of resolving a dispute by providing each sides' needs and adequately addressing their interests so that they are satisfied with the outcome.

\section{Teaching}

Teaching are those systematic activities by which the teacher helps pupils to learn to do certain things that will help them cope with and improve their environment (Mpofu, 1994). Teaching, therefore, include imparting knowledge, skills, inducing learning, indoctrinating and conditioning.

\section{Learning}

Learning is seen by Weithen (2005) as a relatively durable change in behaviour or knowledge that is due to experience. The change of behaviour may be shown in either the way a person thinks, acts or feels (Mwamwenda, 1995).

\section{Peace}

Peace means adopting non-destructive ways to settle conflict and to live in harmony (Abebe, Gbesso and Nyawalo, 2006).

\section{Ethnocentrism}

Ethnocentrism implies viewing and interpreting reality only in terms of one's cultural beliefs and values (Gwirayi, 2010).

\section{Xenocentrism}

Xenocentrism means looking at reality in terms of other people's cultural beliefs and values and having total disregard of one's culture (Gwirayi, 2010).

\section{Culture and Religion}

Culture is the whole way of life of people and religion is part of culture (Gwirayi, 2010). Religion is made up of three areas namely: beliefs and values, religious leaders and followers and social institutions and networks (Moix, 2006). Culture consists of language, symbols and artefacts, interaction patterns and shared values, beliefs, norms and expectations (Gwirayi, 2010).

\section{Multi-cultural education}

Abdulla (2009, p. 160) contends that multi-cultural education refers to the learning of cultures and other differences which include race, ethnicity, religion and so forth. Through this type of education children should develop appropriate knowledge, attitudes and skills related to the respect and appreciation of different cultural differences.

\section{Inter-faithism}

Inter-faithism means people of different faiths learning about faiths different from theirs to respect and appreciate other faiths (Moix, 2006).

\section{Theoretical Framework}

The study is premised on ethnography that is, cultural analysis. Ethnography means writing about people (Goldbart and Hustler, 2005 p.26). The distinctive features of ethnography revolve around the notion that people are meaning makers and an understanding of how 
people, their worlds, the need to understand the particular cultural worlds in which people live and in which they both construct and utilize is necessary (Goldbart and Hustler, 2005). People are seen as collaborating in the construction and maintenance of cultural meanings which inform their actions.

\section{Empirical Literature Review}

A multiplicity of literature attests to how culture and religion could lead to effective conflict resolution in schools. Religion can lead to conflict resolution if a multi-faith approach is adhered to (McGettrick, 2005; Manson, 2005; Barker and Anderson, 2005; Moix 2006). Christian schools should contribute to unifying people through teaching love, care and compassion, an appreciation of beauty and service to others (McGettrick, 2005). There is need for schools to practice the study of not only one religion but the world's religions as is the case in Scotland for the 5-14 year olds and that the school should promote unity of spiritualities and feeling among different faith groups (McGettrick, 2005). McGettrick, also argues for the exploration of common themes, common issues, common practices and common beliefs. Fundamentalism, it is argued, will not promote harmony, peace and equality. Fundamentalism entails views being held with conviction and passion that is ideas, beliefs and practices which are contrary to the common good.

Manson (2005) advises that schools should adopt a rights based approach to diversity in schools. This, Manson states, would be taking the humanist view / principles rather than a religious view. The humanist principle requires concern for the common good and commitment to human rights. This entails also shared human values and mutual respect. Manson (2005) also suggests that if faith schools do not promote inclusivity they have to be done away with.

Barker and Anderson (2005) point out that there exists an inter-faith education centre in Bradford in England that provides multi-faith activities including religious assemblies. The Centre aims at promoting friendship by encouraging children to reflect on these fundamentally different beliefs and how they can embark on joint action to create a cohesive community in the context of plurality.

In the United States of America, Totterdell (2005) reveals that Horace Mann advocated for a common school including the inculcation of Christian morals where the Bible was used but its use confined to portions of the Bible agreeable to all sects.

With regard to the effect of the predominant religion in the community around the school, Moix (2006) advances three areas of religion that could make religion aid conflict resolution or not. These three are religion as beliefs and values, religion as leaders and followers and religion as social institutions and networks. Beliefs and values can cause serious conflict when there are overriding religious traditions or beliefs in the society or community that tend to override other religions and when religious teachings expressed by those in conflict tend to influence discussions and behaviour of those in conflict. If religious beliefs and values respected in the society encourage constructive conflict resolution and religious negatives or teaching provide for a move away from violence or provide for peaceful settlement, religion could be serving a conflict resolution function (Moix, 2006).

If the religious leaders and followers are actively involved in fanning conflict, then conflict could escalate. If leaders help to counter conflict and if they have resources that could help in mitigation and resolution of religious conflict, religion will be aiding conflict resolution (Moix, 2006). The religious institutions and organisations or social structures could fan conflict 
leading to its escalation. On the other hand, if the institutions and their structures are positively involved in conflict resolution then religion could lead to conflict resolution (Moix, 2006).

In Zimbabwe, there is evidence that religions like African Traditional Religion are looked down upon.Marashe, Ndamba and Chireshe (2009) found out that African Traditional Religion was neglected and very little was done to remedy the situation. The syllabus at junior level was found to be Christocentric and textbooks were found to be biased towards Christianity. The researcher recommended revision of Grade $3-7$ resource books, an incorporation of traditional stories, poems and drama and inclusion of African Traditional items in the examination.

Matsika (2012) has also shown how erosion of African culture during colonialism in Zimbabwe has led to divisions. Matsika (2012) and Ngara and Chung (1985) argue that there would be less divisions in Zimbabwe if good values and beliefs from the western culture and African culture were taught in schools implying resorting to multiculturalism.

Nairaland forum, June 23 (2015) reports of the Apostolic Faith in Gwanda resisting immunisation at school because of religious beliefs which do not accept immunisation. This causes conflict between the religious sects and school authorities.

Culture is affected by ethnocentrism, xenocentrism and cultural relativism (Gwirayi, 2010). Ethnocentrism implies viewing and interpreting reality only in terms of one's cultural beliefs and values. In Zimbabwe there are reports of an uproar against Shona speaking teachers in Ndebele primary schools because parents and officials argue that they do not know the language and the culture of the Ndebele people (Sunday News, July 15, 2014); Standard, June 29, 2014; Nehanda Radio, July 22, 2014). Xenocentrism means looking at reality in terms of other cultural beliefs and values and having a total disregard of one's culture, while cultural relativism implies studying and appreciating other people's cultures. In Zimbabwe, xenocentrism might manifest itself when African children have a total disregard of the African culture and uphold Western culture. In Zimbabwe, a variety of views related to ethnocentrism have been advanced by some academics. Mangena (2006) posits that the moral education programmes in Zimbabwean schools should include social values, norms and attitudes. Mavhunga (2006); Matsika (2012) and Makuvaza (2008) argue for the School curriculum that incorporates some indigenous knowledge rooted in African culture.

Mavhunga and Matsika advocate for the crafting of national educational philosophies encapsulating African cultural values (Ubuntu / Unhu) rooted in African Culture. Unhu / Ubuntu is rooted in African culture characterised by such qualities as; responsibility, honesty, justice, trustworthiness, being hardworking, integrity, a co-operative spirit, solidarity, devotion to family and welfare of the community (The Report of the Presidential Commission of Inquiry into Education and Training, 1999 cited in Mavhunga, 2006). Kazembe (2010) advocates the inclusion of information regarding African traditional medicine and traditional religion in the Zimbabwean school curriculum from the primary school to tertiary level. Ethnocentrism and xenocentrism fan conflict and might make its resolution become problematic.

When children come to school, they bring with them different perceptions and values for they come from diverse cultural backgrounds. Children therefore, rely on their cultural backgrounds to determine whether their learning experiences in school are meaningful to them (Gwirayi, 2010). Hence, Gwirayi (2010) indicates that teachers must learn about the 
culture of children they teach or community in which the school is located. Gwirayi (2010) also encourages that cultural relativism should be upheld in primary schools. Authorities like Kasambira (1998); Abdulla (2009) and Banks and Banks (1995) refer to cultural relativism as multiculturalism. Abdulla (2009, p.160) contends the multicultural education refers to learning of cultures and other differences which include race, ethnicity, religion and so forth." What is implied in this statement is that the children should develop appropriate knowledge, attitudes and skills related to the respect and appreciation of different cultures and differences.

In a study on conflict prevention, management and transformation in Zimbabwean schools, Tumbo and Moyo (2013) had participants urging churches to desist from criticising the African Religion thereby fuelling conflict.

Kimmel (2006) and Ngara and Chung (1985) advocate for the creation of micro-cultures to avert misunderstanding and breakdown in relations. Misunderstandings arise from the fact that some people think other people should share their expectations and assumptions, that is, their mindsets. Nowadays, because societies are fluid, there is nothing like a common culture that shapes their behaviour (Pedersen, 2006). Pedersen (2006) points out that some of our cultural teachers are friends, enemies, relatives, heroes, heroines and fantasies to name a few. These have a bearing on an individual's culture.

Kimmel (2006) also attests to the need for professional training in intercultural exploration to achieve understanding and develop communication skills. This could be done through role play and feedback from intercultural communication specialists and cultural representations to facilitate empathetic collaboration, intercultural communication and problem solving. During training, trainees should be made to gain subjective insight into how their own culture is perceived by others and how its assumptions and strategies contribute or detract from cross cultural interaction (Kimmel, 2006).

Kimmel (2006) and Moyana (1989) also advocate for constructive controversies and peace building as some strategies to aid in the resolution of culturally related conflict. Pedersen (2006), on the other hand, developed two cultural grids, that is, the within person cultural grid and between personal cultural grid.

With regards to Zimbabwean Schools, Tumbo and Moyo (2013), found out some cultural and social norms that render children vulnerable to conflict namely: discriminatory exposure of culture to education, poverty, sexual abuse, belief that children should not have a say in society, bad role modelling by parents, failure by parents to pay school fees for their children and child headed families. They also found out that cultural practices like, respecting each other in whatever people are doing was an effective way of solving conflicts.

Modern practices such as exposing children to explicit content that they are not supposed to see were found by Tumbo and Moyo (2013) as resulting in a culture that has a negative effect on conflict resolution.

\section{Research Paradigm}

\section{METHODOLOGY}

This study was mainly qualitative. This approach is sometimes referred to as the subjective approach (Cohen and Manion, 1994). Neuman (1997) refers to it as the interpretive paradigm. The interpretive paradigm posits that social reality is obtained from people's definition of it and culture shapes these definitions (Neuman, 1997). Culture can change from time to time so 
do social reality. This paradigm respects the common sense aspect. It is for this reason that the researcher adopted this paradigm.

\section{Research Design}

Conflict resolution is a multidimensional phenomenon and can only be understood by taking an intensive study of the views by which various cultural and religious groups view conflict and how it can be resolved. The researcher drew largerly on the case study. This was an intrinsic case study where no attempt was made to generalise beyond the single case or even to build theories (Silverman, 2010). Ethnography was adopted in the study. Ethnography means writing about people and involves cultural analysis (Goldbart and Hustler, 2005). Since the effect of culture and religion on conflict resolution was the focus of the study ethnography was found to be ideal.

\section{Data Generation Instruments}

The instruments for data generation were the open-ended questionnaire, focus group discussion schedules, in-depth interview schedules and Delphi schedules. The open-ended questionnaires enabled the researcher to gather data because it is easier to construct and cheaper to administer (Denzim, 1997). The processing of information from questionnaires is less complex compared to observation (White, 2005). Open-ended questionnaires had the advantage that they were ideal in gathering opinions (Anderson, 1994). Open-ended questionnaires have also the advantage of gathering opinions (Anderson, 1994). They also have the advantage of gathering data relatively simple, cheaply and in a short space of time from several locations (Anderson, 1990). Individual in-depth interviews enabled participants to express unique or controversial perspectives without fear of censure or with complete confidentiality, unlike the focus group interviews (Cresswell, 2008). The confidentiality allowed participants complete freedom to describe their world view. In-depth interviews allowed for probing and follow-up questions (Patton, 1987). Probing deepened the response to the question, increased the richness being obtained and gave cues to the interviewee about the level of responses that were desired (Berry, 1992). Focus group interviews were a collective interview. In collective interviews participants, through their interaction could provide data and some insights which could not be revealed through interviews with individuals. Focus groups resulted in a collective synergy, that helped to explore and clarify participants perceptions that could not be readily accessible in a one - on - one interview (Kruger and Casey, 2000 cited in Gall et al., 2007). The focus groups also helped participants to overcome the problem of reluctance to participate / contribute. The Delphi captured ideas from experts. This helped subjects to improve accuracy of results by being exposed to the information from others before coming up with the final ideas.

\section{Selection of Participants and Informants}

Shurugwi district has 35 primary schools the sample consisted of 10 primary schools that were conveniently sampled. The sample of teachers was 93 teachers include 6 heads and 4 deputy heads. The teachers were purposive sampled. Only those who showed interest in the area were chosen. The sample of children consisted of 2 children at infant level, 2 children at middle junior and 2 children at upper junior. These were provided by their respective class teachers. The total sample for the children was 60. The Delphi group consisted 2 experts who were chosen through snow balling. The District Education Officer of Shurugwi District also constituted the sample. 


\section{Data Collection Procedures}

First permission was sought from the Ministry of Primary and Secondary Education then research assistants were trained, focus group discussions were carried out, in-depth interviews were undertaken and lastly the Delphi were undertaken. The whole process took one and half years. Only ten teachers and seven children were subjected to in-depth students.

\section{Sufficiency and Saturation}

The number of participants did not determine the power of the research and the criteria of sufficiency and saturation were used to determine the number of participants interviewed in the study following the advice of Rossman and Rallis (2003). The point of saturation was reached when information from participants provided began to repeat itself through the participants' voice. In the case of interviews with teachers saturation occurred at 10 and for children it occurred at 7.

\section{Data Analysis Procedures}

The researcher followed Merriam's (2009) analysis of qualitative data. These included;

a) organising and preparing data for analysis that is, transcribing interviews, and data focus group notes and arranging the data into different types of sources;

b) reading and re-reading data to get the sense of data and listing of broad themes. There after detailed analysis followed, which began by coding. Data for this study were coded according to the effect of religion and culture on conflict resolution.

c) When themes were identified the researcher read through the notes again, noting relationships among themes and pertinent features within the themes and finally

d) there was the choice of one category and the relation of all other categories to that category.

\section{Trustworthiness of Collected Data}

Trustworthiness encompassed issues such as credibility, dependability, transferability and conformability (O'Leary, 2004). Credibility was enhanced through triangulation of multiple sources of data and a variety of informants. The focus group discussions had those ties with in - depth interviews. Dependability was enhanced through use of focus group discussions and in-depth interviews. With regard to transferability, the researcher used thick descriptions of the process to allow other researchers who might want to research the same phenomenon to easily do so. Conformability was assured by letting the study critiqued at workshops.

\section{Pilot Study}

The questionnaire instrument was pilot tested with 5 teachers while the in-depth interview was tested on 2 teacher colleagues in one school. The focus group discussion guide was piloted test at the same school. The pilot testing was intended to establish whether the participants would not get any difficulties in interpreting items. The pilot testing led to refining of items that resulted in participants getting what the researcher wanted to solicit from them.

\section{FINDINGS}

The findings are presented by sex and where the teachers are operating. For the children only the aspect of where they attend school was considered. Hundred percent $(n=32)$ of Shurugwi Urban Primary School female teachers in response to question 14 of the questionnaire pointed out that culture and religion could lead to the escalation of conflict and could also be used in the resolution of conflict. They pointed out that these lead to conflict when differences in culture and religion were emphasised but if good values and beliefs were emphasized, they could lead to constructive conflict resolution. These, they pointed out, are difficult forms of conflict. They gave some examples of some Apostolic Faith Churches which do not want their 
children to be immunised. They chose not to attend school on the day when immunisation was carried out or left classes purporting to get to the toilet and never to come back. Their religious doctrines forbid them from the use of modern medicines. They claim they become unclean when they receive such treatment. Below is a remark from one teacher:

Some Apostolic Faith churches do not want their children to be immunised leading to the escalation of conflict between children and teachers. They claim treatment is unclean (female teacher).

Absenting themselves means losing lessons, whenever differences between pupils or teachers arose; those who arbitrate conflict cases tend to take sides depending on their culture or religion leaving the other party not satisfied.

Hundred percent $(n=32)$ of teachers in response to Question 14 of the questionnaire indicated that those who resorted to African religion were subjects of the devil because their religion was associated with witchcraft and sorcery. Children whose parents were n'angas (traditional healers) were isolated. This affects their learning they said. Some of the participants in interviews and focus group discussions made the following remarks;

African religion is devilish because we link it to witchcraft and sorcery. Children of n'angas are regarded as children of witches and they are resented by most children and teachers in this school (female teacher).

African religion is associated with witchcraft and sorcery. We need to adopt European associated religions to lead to conflict resolution (female teacher).

Seventy percent $(n=21)$ of the Shurugwi Urban Primary School male teachers in response to question 14 of the Questionnaire claimed that religion and culture can lead to conflict escalation sometimes but can also be used in conflict resolution. They pointed out that those who handled cases of conflict were biased because of their own culture and religion. Below is a remark from one teacher:

Teachers and Heads who handle conflict from cultural differences and religious differences are in most cases biased towards the culture and religion they belong to. The result is that the outcomes are not accepted by the other party (male teacher).

Religion, they pointed out, can escalate conflict if there is intolerance of other religions by leaders or those handling cases of conflict. They expressed that culture could have a negative effect or positive effect depending on the approach of the arbitrator.

Hundred percent $(n=25)$ of the Shurugwi Rural Primary School female teachers in response to question 14 of the Questionnire pointed out that culture and religion could sometimes escalate conflict but at times could help resolve conflict. When constructive values and beliefs were emphasised for example, tolerance, forgiveness, sympathy, sharing and empathy conflict might be resolved amicably. They pointed out that, because of the need for identity, religious and cultural leaders would like to emphasise differences which caused conflict among teachers as well as pupils. The teachers pointed out that not much is known about other religions except Christianity. One teacher indicated that some religions purported certain disabilities were a result of a curse and that they were contagious leading to the discrimination of the affected children. 
Hundred percent $(n=13)$ of the Shurugwi Rural Primary school male teachers in response to question 14 of the Questionnaire also indicated that culture and religion had both a constructive and destructive effect on conflict resolution. They pointed out that if differences in cultures were emphasized, conflict resolution became difficult but if common grounds were emphasized, this might lead to constructive conflict resolution. They pointed out that African religion was the most shunned because it was associated with witchcraft and sorcery.

There seemed to be no differences in opinion about the effect of religion and culture on conflict resolution between Shurugwi urban and rural teachers. There also seemed to be no differences in opinion on the effect of religion and culture on conflict resolution between Shurugwi male and female teachers.

\section{Views of pupils from focus groups and interviews}

The majority of the pupils in focus groups and interviews for Shurugwi urban primary schools pointed out that they regarded African traditional religion as associated with witchcraft and so they shunned it. This, they indicated, was information they were given at home to shun religions and denominations which their parents did not practise. Below is a sentiment from a pupil:

Our parents teach us to disregard African Religion because it has something to do with witchcraft (Pupil)

They, therefore, indicated that they were not free to associate with pupils from other religions and denominations. They were also taught not to accept foodstuffs from anyone for fear of being bewitched. They were to share whatever they had with only those they knew and had approval from their parents. Below is a remark from a pupil:

We are taught not to accept foodstuffs from other children at school because we will be bewitched. We follow what we are told because we are supposed to obey our parents. We cannot share what we have brought from home (Pupil).

At home they were taught to accept what they were told by elders and so they had to accept what they were told by their elder brothers or peers and older sisters, the teachers and those in school administration without questioning. Girls were regarded as lower in status than boys and had to be under boys all the time, the pupils said. One pupil had this to say:

In our culture girls are always supposed to be under boys (girl pupil).

They said good values like sharing, forgiving, helping and sympathy led to constructive conflict resolution. One pupil remarked:

We are taught to observe good values like sharing, forgiving, helping and sympathy. These lead to conflict resolution (boy pupil).

The pupils from Shurugwi Rural primary schools brought out the points mentioned by the pupils in Shurugwi urban but said if they were older members in their families and were used to giving orders to the younger ones, they would find it difficult to receive orders from their peers. Below is what one pupil actually said:

I am the elder son in the family and am used to giving orders to the young ones in the family. I find it difficult to obey orders from group leaders and prefects at school (boy pupil). 
The majority in focus group discussions and interviews expressed the prominence of Christianity in their families and indicated they knew very little about other religions and cultures, hence, the absence of religious tolerance. Below is an example of what one pupil pointed out:

The only religion we accept is Christian religion other religions and cultures have bad teachings (girl pupil).

Both Shurugwi urban and rural pupils seemed to point to the fact that both religion and culture played a divisive role.

\section{Views of Experts}

Experts involved in the Delphi concurred that religion and culture could play both a positive and negative role in conflict resolution. They played a negative role when differences in values and beliefs were emphasised and played a positive role when virtuous beliefs and values were emphasised. They recommended multiculturalism and inter-faithism. Below are some of their remarks:

"Generally, cultural differences are fuelling conflicts in our societies. If we could teach cultural tolerance this would aid conflict - resolution in schools (expert).

The expert also recommended inclusion of all pupils in their classes. One expert remarked thus:

"These with disabilities are discriminated against leading to serious conflict. Conflict resolution could be upheld if inclusion was upheld" (expert).

\section{DISCUSSION ON CULTURE AND RELIGION AND THEIR EFFECT ON CONFLICT RESOLUTION}

Three themes emerged from the findings regarding the effect of religion on conflict resolution namely effect of religious beliefs and values, effect of religious leaders and followers and effect of religion and denominational schools as social institutions and networks while themes under culture were effects of norms, beliefs and values, effects of language and effects of xenocentrism and ethnocentrism.

Pertaining to culture it has been identified that different norms, beliefs, values and language negatively affect conflict resolution in primary schools. Religion negatively affects conflict resolution because of promotion of different beliefs and values by religious leaders, school authorities and denominational schools. The presence of xenocentrism and ethnocentrism in the schools is fuelling conflict. There is absence of religious and cultural tolerance. This confirms the views of Makuvaza (2008), Chung and Ngara (1985), Shizha (2008) and Nyota (2008). The constitution of Zimbabwe Amendment number 2 (2013. p29) attest to the fact that Zimbabwe is a liberal democratic country. It attests to the right of every person to be treated equally and not to be discriminated against in terms of nationality, race, colour, tribe, place of birth, ethnic and social origin, language, class, religious beliefs, political affiliation, opinion, custom, sex, gender, marital status or whether they were born out of wedlock. It also points out that people have the right to use the language of their choice (The Constitution of Zimbabwe Amendment Number 2, 2013, p.31).

Gweru District has three private schools, seventy-three public school and fourteen church schools. Both religion and culture have negative and positive effects on conflict resolution 
(Perdesen, 2006; Moix, 2006; Matsika, 2012; Pring, 2005). The negative effects manifest themselves when a particular church or religion presents itself as the only institution of God. Faiths however, do not lead to division if virtuous values are respected (Halstead and McLaughlin, 2005).

Traditional African religion is viewed as linked with witchcraft and sorcery a view confirmed by Matsika (2012) and Nziramasanga Commission of Inquiry into Education and training (1999).

There is general concurrence that virtuous issues of tolerance, love, care and compassion, service to others ought to be upheld. This confirms the views of McGettrick (2005). There is also a general view that the divisive nature of faith or religions should be done away with. This confirms the views of Deer (2005); Totterdell (2005); Gallagher (2005); Levin, (2005) and Barker and Anderson (2005).

The issue of multiculturalism and inter-faithism is also brought out in the findings. This collaborates the views of Manson (2005), McGettrick (2005) and totterdel (2005).

\section{CONCLUSIONS}

From the findings it can be concluded that:

- Aspects of culture and religion are playing a divisive role. There are not helpful in conflict resolution.

- Ethnocentrism exists in parts of the Shurugwi District.

- Xenocentrism affects almost all areas in the Shurugwi district

- All primary schools in the Shurugwi district would like virtuous issues of culture and religion to be upheld.

\section{RECOMMENDATIONS}

From the conclusions advanced above the following recommendations are put forward:

- Primary schools to resort to multiculturalism programmes.

- Primary schools are to resort to inter-faithism programmes in public and faith schools.

- Primary schools are to resort to cultural revolution programmes put forward by Moyana (1989).

- The use of Pedersen's (2006) grids to establish the real culture of school personnel and students and in carrying out staff development on both personnel and students to get them on course that is harmony between behaviour and expectations is to be practised in primary schools.

\section{Further research}

Further research is required in the following area:

- A study with parents on the effect of religion and culture on conflict resolution.

\section{References}

Abdullah, A.C. (2009). Multicultural Education in Early Childhood: Issues and Challenge. Journal of International Cooperation in Education, Vol 12(1): 159 - 175.

Abebe, T. T., Gbesso, A. and Nyawalo, P. A. (2006). University of Peace, Report on the working Committee meeting, on Peace Education in Africa, Addis Ababa Ethiopia: University of Peace.

Anderson, G. (1990). Fundamentals of Educational Research, London: The Falmer Press

Anderson, G. (1994). Fundamentals of Educational Research, (2nded), London: The Falmer Press

Bamboo Web Dictionary (2006). Accessed 03/03/2017 
Saiden, T., \& Makawa, J. D. (2017). Addressing Cultural And Religious Intolerance For Effective Teaching, Learning And Peace Of The Primary School Children In Zimbabwe: A Case Study Of Shurugwi District Schools. Advances in Social Sciences Research Journal, 4(13) 1-15.

Banks, C and Banks, R. (1995). Multicultural Education, New York: North Central Regional Education Laboratory. Berry, J.W. (1992). Cross-cultural Psychology: Research and Application. New York: Cambridge University Press.

Chung, F. \& Ngara, E. (1985). Socialism, Education and Development: A challenge to Zimbabwe. Harare: Zimbabwe Publishing House.

Cohen, L. and Manion, L. (1994). Research Methods in Education (4th Ed), London: Routledge. Constitution of Zimbabwe Amendment (No 20) Act (2013). Harare: Fidelity Printers and Refiners

Cresswell, J.W (2008). Educational Research: Planning, Conducting and Evaluating Quantitative and Qualitative Research. New Jersey: Sage.

Deer, C. (2005). Faith Schools in France: From Conflict to Consensus. . In Gadner, R. Cairns, J. \& Lawton, D. (Eds) Faith schools Consensus or Conflict, London: Routledge Falmer: 181-189.

Deutsch, M. (1973). The Resolution of Conflict. U.S.A: Zale University.

Ferguson, J. (1997). War and Peace in the World's Religions, London: Sheldon Press.

Gallagher, T. (2005). Faith Schools and Northern Ireland: Areview of Research. . In Gadner, R. Cairns, J. \& Lawton, D. (Eds) Faith schools Consensus or Conflict, London: Routledge Falmer: 159-168.

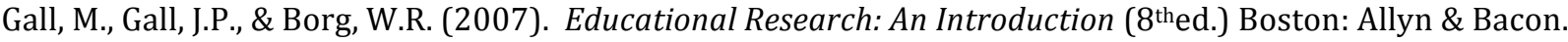

Goldbart, J. and Hustler, D. (2005). Ethnography, In Somekh, B. and Lewin, C. (Eds) Research Methods in Social Science, London: Sage Publications

Gwirayi, P. (2010). Sociology of Education: An Introduction, Gweru: Mambo Press.

Halstead, J.M. \& Mc Laughlin, T. (2005). Are Faith Schools Divisive? In Gadner, R. Cairns, J. \& Lawton, D. (Eds) Faith schools Consensus or Conflict, London: Routledge Falmer: 61-72.

Jandt, F. E. (1985). Win-Win Negotiating: Turning Conflict into Agreement, New York: John Wiley and Sons.

Kasambira, K. P. (1998). Education, Administration and Management, Harare: College Press.

Kazembe, T.C. (2010). Traditional Medicine and Traditonal Religion should be included in School Curriculum in Zimbabwe, In Zimbabwe Journal of Educational Research, 22(1):61-89.

Kimmel, P. R. (2006). Culture and Conflict. In Deustch, M., Coleman, P.T. \& Marcus, and E.C. (Eds) Handbook of Conflict Resolution: Theory and Practice (2 ${ }^{\text {nd }}$ Ed) New York: Jossey Bass: 625-685.

Kreitner, R. and Kinicki, A. (1991). Organizational Behaviour: International Student Edition, 2 ${ }^{\text {nd }}$ Edition, London: Irwin.

Lam, J. (1988). The Impact of Conflict Resolution Programs on Schools: A review and Synthesis of Evidence. Amherst, M. A: Research report prepared for the National Association for Mediation in Education (January).

Levin, L. (2005). Through the looking glass: Religion, Identity and Citizenship in a Plural

Culture. From the view point of the modern Orthodox Jewish School. . Gadner, R. Cairns, J. \& Lawton, D. (Eds) Faith schools Consensus or Conflict, London: Routledge Falmer: 139-145.

Mangena, F. (2006). Issues of Curriculum Development for Moral Development. Zimbabwe Journal of Educational Research, 18(1):1-16.

Marashe, J. Ndamba, G. T. and Chireshe, E. (2009). The Teaching of African Traditional Religion in Primary Schools in Zimbabwe challenges and opportunities. University of Pretoria, http://www.tandfonline.com/loi/usea 20.

Accessed on 20/06/2015.

Matsika, C. (2012). Traditional African Education: It's Significance to Current Educational Practices with Special Reference to Zimbabwe, Gweru: Mambo Press.

Mavhunga, P. J. (2006). Africanising the School Curriculum: A case of Zimbabwe. Zimbabwe Journal of Educational Research, 18(3):440-456.

Mpofu, E. (1994). Towards Successful Teaching, Harare: Books for Africa Publishing. Mwamwenda, T.S (1995). Educational Psychology :An African Perspective (2 ${ }^{\text {nd }}$ ed) Durban: Butterworth.

Moix, B. (2006). Matters of Faith, Religion, Conflict and Conflict Resolution, In Deustch, 
M., Coleman, P.T. and Marcus, E.C. (Eds) the Handbook of Conflict Resolution: Theory and Practice (2 ${ }^{\text {nd }}$ Ed) New York: Jossey Bass: 582-602.

McGettrick, B. (2005). Perceptions and Practices of Christian Schools.Gadner, R. Cairns, J. \& Lawton, D. (Eds) Faith schools Consensus or Conflict, London: Routledge Falmer: 105-112.

Moyana, T.T. (1989). Liberation and the Creative Act. Harare: Zimbabwe Publishing House.

Merriam, S. B. (2009). Qualitative Research: A Guide Design and Implementation, San Francisco: Jossey Bass

Nairaland forum (2015). Apostolic sect puts faith before Children's Rights, Prefers Dead

Kids- Religion 23 June 2015. www.//Apostolic Sect Puts Faith Before Children's Rights. Prefers Dead Kids Religion - Nigeria.htm accessed on 23/06/2015.

Nehanda Radio (2015) .Moyo Summons Dokora over Ndebele Speaking Teachers. https://www.facebook.com/Nehanda Radio/posts 10/52409520156 accessed on 07/05/15

Neuman, L. W. (1997). Social Research Methods: Qualitative and Quantitative Approaches (3rdEd), Boston: Allyn and Bacon.

Rue, L.N. and Byars, L.L. (2003). Management: Skills and Application (10 ${ }^{\text {th }}$ Ed) Boston: McGraw Hill Irwin.

Sellman, E. M. (2003). The Process and Outcomes of Implementing Peer Mediation Services in Schools: A Cultural Historical Activity Theory Approach. Unpublished, D. Phil Thesis University of Birmingham.

Sunday News (2015). Uproar over Non Ndebele Speaking Teachers www.sundaynews .com.zw/uproar-over-nonNdebele speaking -teacher. July 15 accessed 04/05/2015.

The Standard (2014). Minister explains deployment of Non- Ndebele speaking Teachers. www.thestandard.6.zw./.../ minister explains deployment - non-ndebele speaking teachers. June 29 accessed 06/05/15.

Tumbo, D. and Moyo, E. (2013). Key Informants Research Report on Conflict Prevention, Management, Resolution and Transformation for in school Zimbabwean Children, Harare: Environmental Action

Pedersen, P. (2006). Multicultural Conflict Resolution, In Deutsch, M., Coleman, P. T. \& Marcus, E.C. (Eds) the Handbook of Conflict Resolution: Theory and Practice (2 ${ }^{\text {nd }}$ Ed) New York: Jossey Bass: 625-685.

Pring, R (2005). Faith Schools Can they be Justified. In Gadner, R. Cairns, J. \& Lawton, D. (Eds) Faith schools Consensus or Conflict, London: Routledge Falmer: 51-60.

Patton, M. Q. (1987), How to use Qualitative Methods in Evaluation. Newbury Park, CA: Sage Rossman, G. B. \& Rallis, S. F. (2003.) Learning in the field: An introduction to qualitative research, ( $2^{\text {nded }}$ ), Thousand Oaks, CA: Sage.

Shizha, E. (2008). "indigenous ": what indigenous?: Beliefs and attitudes of Rural Primary School Teachers Towards Indigenous Knowledge in the Science curriculum in Zimbabwe In The Australian Journal of Indigenous Education_vol 37: 80-90

Silverman, D. (2010). Doing Qualitative Research, A Practical Handbook. London: Sage

Weiten, W. (2005). Psychology Themes and Variations. New York: Wadworth Language Learning.

Zimbabwe Report of the Presidential Commission of Inquiry into Education and Training, Nziramasanga, C. T. (1999). Harare: Government Printers 